\title{
Combined effects of nitrogen enrichment, sulphur pollution and climate change on fen meadow vegetation $N: P$ stoichiometry and biomass
}

\author{
Jerry van Dijk • Bjorn Robroek • Ignacy Kardel • \\ Martin Wassen
}

Received: 16 March 2011 / Accepted: 14 December 2011/Published online: 31 December 2011

(C) The Author(s) 2011. This article is published with open access at Springerlink.com

\begin{abstract}
Nitrogen (N) and sulphur (S) deposition, as well as altered soil moisture dynamics due to climate change can have large effects on fen meadow biogeochemistry and vegetation. Their combined effects may differ strongly from their separate effects, since each process affects different nutrients through different mechanisms. However, the impacts of these environmental problems are rarely studied in combination. We therefore investigated the separate and interactive effects of current levels of $\mathrm{N}$ - and S-deposition and changes in soil moisture dynamics on fen meadow
\end{abstract}

J. van Dijk ( $\varangle) \cdot$ B. Robroek · M. Wassen

Department of Innovation and Environmental Sciences, Faculty of Geosciences, Utrecht University, P.O. Box 80115, 3508 TC Utrecht, The Netherlands e-mail: j.vandijk2@uu.nl

B. Robroek

e-mail: B.J.M.Robroek@uu.nl

M. Wassen

e-mail: m.j.wassen@uu.nl

Present Address:

B. Robroek

Ecology and Biodiversity Group, Institute of Environmental Biology, Utrecht University, Padualaan 8, $3584 \mathrm{CH}$ Utrecht, The Netherlands

I. Kardel

Department of Hydraulic Engineering, Faculty of Civil and Environmental Engineering, Warsaw University of Life Sciences, ul. Nowoursynowska 159,

02-776 Warsaw, Poland

e-mail: I.Kardel@levis.sggw.pl vegetation. We focused on vegetation biomass and $\mathrm{N}: \mathrm{P}$ stoichiometry, including access to soil $\mathrm{P}$ through root surface phosphatase activity, in a 3-year factorial addition experiment in an $\mathrm{N}$-limited rich fen meadow in the Biebrza valley in Poland. We applied $29.5 \mathrm{~kg} \mathrm{~N} \mathrm{ha}^{-1}$ year $^{-1}$ and $32.1 \mathrm{~kg} \mathrm{~S}^{-1}$ year $^{-1}$, which correspond to current deposition levels in Western Europe. Changes in soil moisture dynamics due to climate change were mimicked by amplified drying of the soil in summer. This level of N-deposition had limited effects on plant biomass production in this rich fen, despite low foliar N:P ratios that suggest $\mathrm{N}$ limitation. This level of S-deposition, however, resulted in decreased vegetation P-uptake and biomass. We also showed that increased summer drought resulted in considerable increases in vegetation biomass. We found no interactive effects on vegetation biomass or $\mathrm{N}: \mathrm{P}$ stoichiometry, possibly as a result of the limited main effects of the separate processes.

Keywords Atmospheric deposition - Soil moisture · Wetland · Peatland · Biogeochemistry $\cdot$ Productivity

\section{Introduction}

Nitrogen $(\mathrm{N})$ deposition, sulphur (S) pollution and global climate change are among the most important external threats to plant species diversity in fens (Bobbink et al. 2010; Lamers et al. 2002b). Through their potential to increase plant nutrient availability, all 
of these environmental problems can increase vegetation productivity, which may have marked effects on plant species diversity (Grime 2001). The specific nutrients that are affected and the mechanisms by which their availability is controlled, however, differ greatly between these three environmental problems.

Atmospheric N-deposition directly increases plant available $\mathrm{N}$, thereby increasing vegetation productivity and reducing plant species diversity (Bobbink et al. 2010). S-pollution can enhance plant phosphorous (P) availability in reduced fen soils by replacing $\mathrm{PO}_{4}$ in iron-phosphate complexes (Lamers et al. 1998; Smolders et al. 2006). On the other hand, high N- and S-loading can also lead to toxic effects on fen plants, reducing their biomass production (Koch and Mendelssohn 1989; Smolders and Roelofs 1996; Lamers et al. 1998). Global climate change may also increase both $\mathrm{N}$ - and P-availability. Climate models predict increased temperatures, increased summer drought and increased occurrence of extreme precipitation events for temperate regions (IPCC 2007). For fens in these regions, this means that the soil will be subjected to increased summer drought and alterations in water level dynamics (Dawson et al. 2003; Reiche et al. 2009). These effects have been shown to increase both $\mathrm{N}$ - and P-availability to plants (Olde Venterink et al. 2002; Van Dijk et al. 2004; Reiche et al. 2009).

Given the wide geographical range of $\mathrm{N}$ - and S-deposition in Europe (Working Group on Effects 2004) and the global impact of climate change, cooccurrence of these problems can be considered a rule rather than an exception. Since the three environmental impacts on fens outlined above act on different nutrients through different mechanisms, their combined impact on fen vegetation may differ from the separate effects of nitrogen deposition, sulphur deposition and climate change individually. Furthermore, feedbacks between the different processes, e.g. through redox processes or by alterations of nutrient stoichiometry, may enhance or mitigate their impact on fen vegetation. However, integrated studies assessing the combined effects of nitrogen deposition, sulphur pollution and altered drying-rewetting dynamics on fen vegetation are currently lacking. This poses serious constraints on our understanding of the response of these ecosystems to global change. We therefore performed a 3-year field experiment in which we applied increased $\mathrm{N}$ - and S-levels equal to current deposition levels in Western Europe and manipulated drying-rewetting dynamics by drainage in a groundwater fed fen meadow in the Biebrza valley, Poland. We investigated the separate and interactive effects of our manipulations on vegetation biomass and N:P stoichiometry.

We hypothesized that: (1) N-addition increases fen vegetation biomass by increasing plant $\mathrm{N}$-availability; (2) N-addition increases plant P-demand and leads to increased phosphatase release by roots to access P-pools in the soil (Johnson et al. 1999; Fujita et al. 2010); (3) S-addition leads to P-release (Lamers et al. 1998; Smolders et al. 2006), but only has minor effects on vegetation biomass and nutrient stoichiometry because plant growth is N-limited; (4) Increased soil moisture dynamics by drainage increases fen vegetation biomass by increasing plant nutrient availability; (5) combined effects of $\mathrm{N}$ - and $\mathrm{S}$-addition lead to a higher vegetation biomass than would be expected at addition of $\mathrm{N}$ and $\mathrm{S}$ individually by altering N:P stoichiometry (Güsewell 2004). In addition to testing these hypotheses, we explored whether increased soil moisture dynamics altered the individual and combined impacts of $\mathrm{N}$ - and $\mathrm{S}$-addition on plant $\mathrm{N}$ - and $\mathrm{P}$-availability and uptake.

\section{Materials and methods}

Site description and experimental setup

In 2006, we set up an $\mathrm{N}$ - and $\mathrm{S}$-addition experiment in a rich fen meadow just outside the town of Lipsk $\left(53^{\circ}\right.$ $44^{\prime} \mathrm{N}, 23^{\circ} 23^{\prime} \mathrm{E}$ ), Poland. The experimental manipulations continued until 2009. The site borders the Biebrza National Park and was chosen to represent semi-natural European fen meadows with low background deposition of $\mathrm{N}$ and $\mathrm{S}$ and minor hydrological changes (Wassen et al. 1996). Background deposition levels in this area of Poland were estimated to be 7-10 kg N ha ${ }^{-1}$ year $^{-1}$ and 5-10 kg S ha ${ }^{-1}$ year $^{-1}$ (Nyíri et al. 2010). Shoot N:P ratio of the control plots remained well below 14 (8.1 on average) throughout the experiment. In fertilization experiments freshwater wetlands, N:P ratios below 14 were shown to indicate N-limitation (Wassen et al. 1995; Koerselman and Meuleman 1996). We recorded 28 higher plant species in the meadow. Five species made up for the major part of the vegetation cover: Calamagrostis stricta (15\%), Carex rostrata (15\%), Holcus lanatus (15\%), Poa palustris (12\%) and C. nigra (10\%). 
In 2006, two plots were established on a seemingly homogeneous part of the meadow with regard to vegetation. Each of these plots was divided into 24 subplots of $1 \mathrm{~m}^{2}(N=48)$, to which we added $\mathrm{N}$ and $\mathrm{S}$ in a full factorial randomized setup $(N=24$ for each treatment), resulting in 12 subplots each for control, $\mathrm{N}$, $\mathrm{S}$ and $\mathrm{N}+\mathrm{S}$ application. To avoid edge effects we applied a buffer strip of $20 \mathrm{~cm}$ wide around each plot in which no $\mathrm{N}$ or $\mathrm{S}$ was applied and no sampling was done. To increase drying-rewetting dynamics, we dug a small ditch around one of the two plots, which was connected to a nearby ditch discharging in a canal. We dug additional ditches through the center of the plot to ensure our manipulation also affected soil moisture conditions in the center of the block. Ditches were carefully cleared of vegetation regrowth each year in April, before the growing season.

$\mathrm{N}$ and $\mathrm{S}$ were applied yearly in April, before the growing season. $\mathrm{N}$ was applied as a combination of $\mathrm{NH}_{4}$ and $\mathrm{NO}_{3}$ using Osmocote slow release fertilizer with an $\mathrm{N}$ content of $23 \%$, equal to an $\mathrm{N}$-enrichment of $29.5 \mathrm{~kg} \mathrm{~N}^{-1}$ year ${ }^{-1}$. $\mathrm{S}$ was applied as $\mathrm{Na}_{2} \mathrm{SO}_{4}$ at a level of $32.1 \mathrm{~kg} \mathrm{~S}^{-1}$ year $^{-1}$. Including the background deposition levels, the total amounts of $\mathrm{N}$ and $\mathrm{S}$ applied yearly in our experiment are slightly above current N- and S-deposition rates in Western European countries with high deposition rates. In The Netherlands for instance, deposition rates equal about $30 \mathrm{~kg} \mathrm{~N}$ $\mathrm{ha}^{-1}$ year $^{-1}$ and $21 \mathrm{~kg} \mathrm{~S} \mathrm{ha}^{-1}$ year $^{-1}$ respectively (Netherlands Environmental Assessment Agency 2009).

\section{Measurements}

Soil moisture content was measured using ThetaProbe ML2x soil moisture sensors (Delta-T Devices Ltd, Cambridge, UK) in 2 random subplots in both the drained and undrained plot at 2 hourly intervals and recorded with two GP1 dataloggers (Delta-T Devices Ltd, Cambridge, UK). The simultaneous measurements in the two subplots were averaged before analysis to account for local spatial variation within the plot. Soil temperature was measured in 1 subplot in both the drained and undrained plot at the same interval. Soil moisture measurements proved unreliable below $1{ }^{\circ} \mathrm{C}$ because of freezing and thawing effects. We therefore only included moisture measurements made at $1^{\circ} \mathrm{C}$ or higher in our analysis.

Peak standing biomass was used as an approximation of vegetation productivity. Thereto, aboveground biomass was harvested yearly in the second week of June (approximating peak standing biomass) by clipping a $20 \times 20 \mathrm{~cm}$ square in each subplot. The location of clipping within each subplot was varied each year. Fresh biomass was oven dried and weighed. Dried samples were used to determine $\mathrm{N}: \mathrm{P}$ ratio of the vegetation.

Soil pore water was sampled in 2008 and 2009 at the time of harvest in each subplot using Rhizon soil moisture samplers (Eijkelkamp Agrisearch Equipment, Giesbeek, The Netherlands). Due to analytical constraints, we were not able to analyze pore water samples in 2007. EC and $\mathrm{pH}$ were measured in the field using standard electrodes (WTW GmbH, Weilheim, Germany). Pore water samples were stored refrigerated in closed syringes for a maximum of 2 days until transport to the lab for further analysis. Major ionic composition was measured on a Dionex ICS-1000 ion chromatograph. Phosphate concentrations were determined colorimetrically using a UNICAM UV/VIS Helios Alpha spectrometer. Because drainage can alter the relative input of ground- and rain-water, thereby altering pore water biogeochemistry (Van Dijk et al. 2004), we calculated the ionic ratio, which is the ratio of $\mathrm{Ca}$ and $\mathrm{Cl}$ concentrations and is a measure for the relative input of groundwater and rainwater. The method is based on the notion that rainwater derived $\mathrm{Cl}$ is a very conservative ion, while $\mathrm{Ca}$ is mainly derived from dissolution of subsurface minerals. Low ionic ratios thus indicate a larger influence of rainwater relative to groundwater (Van Wirdum 1991).

At the start of the experiment we introduced Phalaris arundinacea as a model plant in all plots to study the effects of our treatments on root surface phosphatase activity and plant $\mathrm{N}: \mathrm{P}$ stoichiometry, similar to our earlier use of these plants as phytometers in a greenhouse experiment (Robroek et al. 2009). However, introduced $P$. arundinacea plants declined strongly, so that it was absent from many of our plots in the 2 years, thereby limiting comparison between treatments. We therefore switched to C. nigra, which is also a characteristic plant species of peat meadow vegetation and was found in all of our subplots. C. nigra has comparable plant traits to the other dominant species in the vegetation, including an association with arbuscular mycorrhizal fungi (Wang and Qiu 2006) and intermediate flooding tolerance (Visser et al. 2000; Van Bodegom et al. 2008). Data from $P$. arundinacea were not included in our analysis, but the results are presented here for comparison. C. nigra plants 
including roots were harvested in 2008 and 2009 for determination of root surface phosphatase activity, using a modified $p$-nitrophenyl phosphate assay (see Robroek et al. 2009 for details). After phosphatase measurement, $C$. nigra plants were dried for determination of shoot $\mathrm{N}: \mathrm{P}$ ratios (mass based).

Dried shoot biomass samples were pre-cut by hand and ground and homogenized using a Herzog grinding mill (HERZOG Maschinenfabrik GmbH+Co., Osnabrück, Germany). Several C. nigra samples proved to be too small for automated grinding. These were hand ground using mortar and pestle. Six samples yielded too little material for subsequent analysis, hence the lower number of replicates in the analysis of $\mathrm{N}: \mathrm{P}$ ratio. Nitrogen content was determined on a Carlo-Erba C:N analyser. $\mathrm{P}$ content was measured using ICP-OES after destruction with HF.

\section{Statistics}

Prior to analyses, all data were tested for normality and equality of variances. In case of violation of the assumptions of equality of variances, data were logtransformed.

We tested for significant separate effects and interaction effects of our treatments $(\mathrm{N}$ - and S-addition and drainage) over time using a repeated measures ANOVA.

We considered soil moisture and temperature measurements in the drained and undrained plots as paired observations, because they are partly determined by the same site conditions such as groundwater level and local meteorological conditions. We therefore used paired samples $t$ tests to test for differences in soil moisture content and soil temperatures between these treatments for the overall data and for each year separately. These analyses were performed using SPSS 15.0.

We calculated minimal detectable effects with a power analysis based on our data, using the software package G*Power 3.1.3 (Faul et al. 2007).

\section{Results}

Soil moisture dynamics and temperature

Average soil moisture content during the experiment was slightly but significantly $(P<0.001)$ higher in the undrained plot (97.0\% of total water saturation) than in the drained plot (96.7\%). Between N and S-addition and harvesting, the same significant difference was present, with soil moisture contents of 98.1 and $97.5 \%$ for the undrained and drained plot respectively. Despite the limited effects on average soil moisture content, the ditches around the plots increased the extremes in soil moisture content in dry periods, when the drained plots became drier than the undrained plots (with differences up to 4\%; Fig. 1).

Averaged over all years and seasons, the soil temperature of the drained plot $\left(7.7^{\circ} \mathrm{C}\right)$ was slightly but significantly higher than the soil temperature of the undrained plot $\left(7.6^{\circ} \mathrm{C}\right)$. In the period between $\mathrm{N}$ - and $\mathrm{S}$-addition and harvesting, average soil temperature was significantly higher in the drained plot $\left(13.0^{\circ} \mathrm{C}\right)$ than in the undrained plot $\left(12.6^{\circ} \mathrm{C}\right)$.

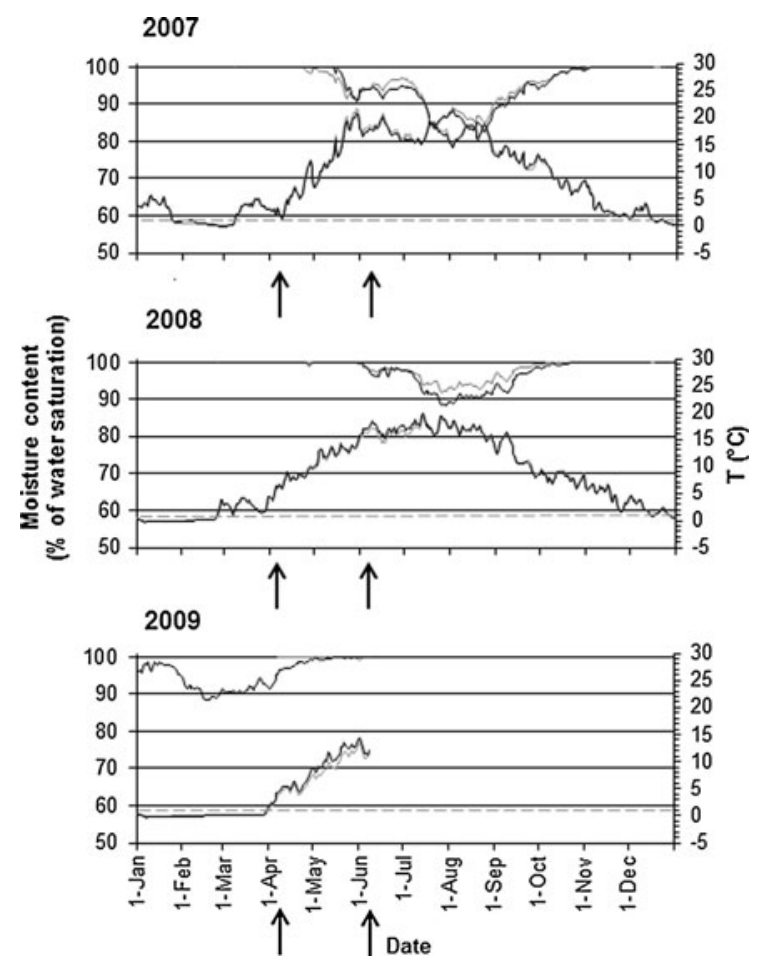

Fig. 1 Daily average soil moisture content (as percentage of total water saturation, upper lines) and soil temperature (lower lines). Grey lines represent the undrained plot, black lines represent the drained plot. The time line for each graph is identical, starting at January 1 and continuing until December 31 of each year. Arrows indicate the time of fertilizer application (April) and harvesting (June). The dashed line indicates $1{ }^{\circ} \mathrm{C}$, below which soil moisture measurements proved to be unreliable 
Pore water chemistry

Pore water ionic ratio was high (range: 0.965-0.998 and remained relatively constant throughout the study. Additionally, this ratio was not affected by any of our treatments (Table 1).

S-addition significantly increased pore water sulphate concentrations, but the effect depended both on time and the drainage treatment. Overall, sulphate concentrations increased over time but were only significantly increased by S-addition in 2009 (Fig. 2). Drainage enhanced the effect of S-addition on pore water sulphate concentrations.

Both pore water inorganic $\mathrm{N}$ and $\mathrm{PO}_{4}$ concentrations increased significantly over time, but were not affected by any of our treatments.

\section{Plant response}

S-addition significantly increased the N:P ratio of C. nigra from 7.91 to 9.01 on average (Fig. 3a). This increase was caused by a significant reduction of C. nigra $\mathrm{P}$-content without affecting $\mathrm{N}$-content (Table 2). S-addition did not affect the N:P ratio of the total biomass (Fig. 3b).

No main effects of either drainage or $\mathrm{N}$-addition on plant response parameters were identified, but there was a significant interaction effect of $\mathrm{N}$-addition and the drainage treatment on phosphatase activity (Table 1). When we analyzed drained and undrained conditions separately, we found that $\mathrm{N}$-addition significantly increased root surface phosphatase of C. nigra under undrained conditions, while under drained conditions, no significant effects of $\mathrm{N}$-addition on phosphatase activity were found. Average phosphatase activity under drained conditions was $2.17 \cdot 10^{-2} \mathrm{mg} \mathrm{4-NP} \mathrm{hr}{ }^{-1} \mathrm{~g}^{-1}$ fresh weight root.

Vegetation response

Vegetation biomass differed significantly between sampling years (Table 1) and was highest in 2008.

Table 1 ANOVA table for the repeated measures ANOVA's testing the main effects and interactions of time, nitrogen enrichment, sulphur pollution and drainage on pore water chemistry and plant responses

\begin{tabular}{|c|c|c|c|c|c|c|c|c|}
\hline & Time & $\mathrm{N}$ & $S$ & Drainage & $\mathrm{N} \times \mathrm{S}$ & $\begin{array}{l}\mathrm{N} \times \\
\text { drainage }\end{array}$ & $\begin{array}{l}\mathrm{S} \times \\
\text { drainage }\end{array}$ & $\begin{array}{l}\mathrm{N} \times \mathrm{S} \times \\
\text { drainage }\end{array}$ \\
\hline \multicolumn{9}{|l|}{ Pore water chemistry } \\
\hline Ionic ratio $(\mathrm{Ca} /(\mathrm{Ca}+\mathrm{Cl}))^{\mathrm{a}}$ & n.s. & n.s. & n.s. & n.s & n.s. & n.s. & n.s. & n.s. \\
\hline $\mathrm{SO}_{4}^{\mathrm{a}}$ & $48.01 * * *$ & n.s. & $\uparrow 41.90^{* * *}\left(11.40^{* *}\right)$ & n.s. & n.s. & n.s. & $13.41 * * *$ & n.s. \\
\hline $\begin{array}{l}\text { Total N } \\
\left(\mathrm{NO}_{2}+\mathrm{NO}_{3}+\mathrm{NH}_{4}\right)^{\mathrm{a}}\end{array}$ & $123.4 * * *$ & n.s. & n.s. & n.s. & n.s. & n.s. & n.s. & n.s. \\
\hline $\mathrm{PO}_{4}^{\mathrm{a}}$ & $51.57 * * *$ & n.s. & n.s. & n.s. & n.s. & n.s. & n.s. & n.s. \\
\hline \multicolumn{9}{|l|}{ Plant response } \\
\hline C. nigra $N$ concentration ${ }^{\mathrm{a}}$ & $32.47 * * *$ & n.s. & n.s. & n.s. $(4.74 *)$ & n.s. & n.s. & n.s. $\left(4.18^{*}\right)$ & n.s. \\
\hline C. nigra $\mathrm{P}$ concentration ${ }^{\mathrm{a}}$ & $21.14 * * *$ & n.s. & $\downarrow 4.29^{*}$ & n.s. & n.s. & n.s. & n.s. & n.s. \\
\hline C. nigra $\mathrm{N}: \mathrm{P}$ ratio ${ }^{\mathrm{a}}$ & n.s. & n.s. & $\uparrow 12.37 * * *$ & n.s. & n.s. & n.s. & n.s. & n.s. \\
\hline $\begin{array}{l}\text { C. nigra phosphatase } \\
\text { activity }^{\mathrm{a}}\end{array}$ & $25.43 * * *$ & n.s. & n.s. & n.s. & n.s. & $4.757 *$ & n.s. & n.s. \\
\hline \multicolumn{9}{|l|}{ Vegetation response } \\
\hline Biomass & $48.70 * * *$ & n.s. & $\downarrow 5.72 *$ & $\uparrow 13.89 * * *$ & n.s. & n.s. & n.s. & n.s. \\
\hline Biomass $\mathrm{N}$ concentration & $112.4 * * *$ & n.s. & n.s. & n.s. & n.s. & n.s. & n.s. & $5.461 *$ \\
\hline Biomass $\mathrm{P}$ concentration & $15.89^{* * * *}$ & n.s. & n.s. & n.s. & n.s. & n.s. & n.s. & n.s. \\
\hline Biomass N:P ratio & $67.77 * * *$ & n.s. $(4.78 *)$ & n.s. & n.s. & n.s. & n.s. & n.s. & n.s. \\
\hline $\mathrm{N}$ standing stock & $36.50 * * *$ & n.s. & n.s. & n.s. & n.s. & n.s. & n.s. & n.s. \\
\hline P standing stock & $22.08 * * *$ & n.s. & n.s. & n.s. & n.s. & n.s. & n.s. & n.s. \\
\hline
\end{tabular}

$F$ values are presented with $P$ values indicated by asterisks. $F$ values of significant time interactions are given between brackets. The direction of main effects of N, S and drainage are indicated with arrows ( $\uparrow$ positive effect, $\downarrow$ negative effect)

n.s. not significant

* $P \leq 0.05$; ** $P \leq 0.01$; *** $P \leq 0.001$

${ }^{\text {a }}$ Data from 2008 and 2009 only 


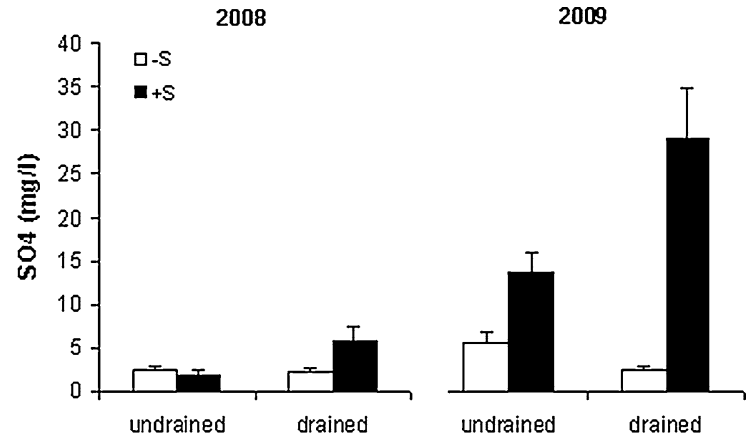

Fig. 2 Average $\mathrm{SO}_{4}$ concentration in the soil pore water in 2008 and 2009 in the undrained and drained treatment. White bars represent plots without $\mathrm{SO}_{4}$ addition, black bars represent plots with $\mathrm{SO}_{4}$ addition. Error bars indicate standard error $(N=24)$
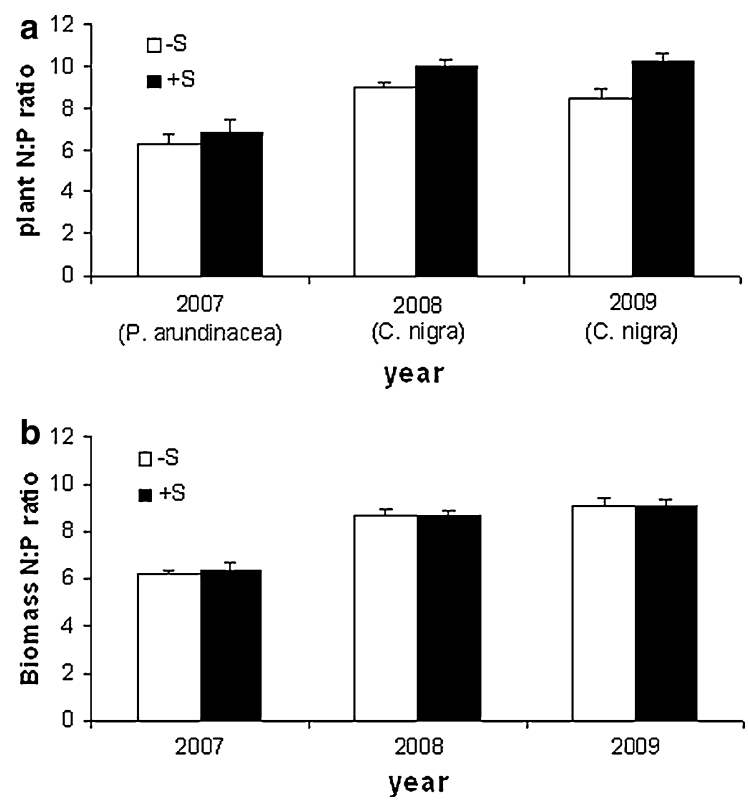

Fig. 3 a Plant N:P ratio without (white bars) and with $\mathrm{SO}_{4}$ addition (black bars). Differences are significant at the 0.001 level. Error bars represent standard errors $(N=18)$. b Total vegetation biomass $\mathrm{N}: \mathrm{P}$ ratio without (white bars) and with $\mathrm{SO}_{4}$ addition (black bars). No significant differences were found. Error bars represent standard errors $(N=24)$

S-addition significantly reduced vegetation biomass (Fig. 4a), while drainage significantly increased vegetation biomass (Fig. 4b).

Overall vegetation $\mathrm{N}: \mathrm{P}$ ratios ranged between 6.5 and 9.4. Overall vegetation $\mathrm{N}: \mathrm{P}$ ratios increased significantly over time. $\mathrm{N}: \mathrm{P}$ ratios in the $\mathrm{N}$ treatment showed a steep increase from 2007 to 2008 but did not change between 2008 and 2009 (Table 2). N:P ratios in treatments without $\mathrm{N}$-addition showed a more steady increase over time. Standing stock of $\mathrm{N}$ and $\mathrm{P}$ increased over time, but were not affected by any of our treatments.

\section{Discussion}

Current levels of $\mathrm{N}$ - and S-deposition in Europe have been reduced considerably in the past decades due to effective environmental policies and stricter emission regulations (Working Group on Effects 2004). Current levels of $\mathrm{N}$-deposition in Western Europe now fall within the range of critical $\mathrm{N}$ loads defined for rich fen ecosystems (15-35 kg N ha ${ }^{-1}$ year $^{-1}$; Bobbink et al. 2010). Accordingly, and in contrast with earlier addition experiments (e.g. Lamers et al. 1998), we chose to apply $\mathrm{N}$ and $\mathrm{S}$ in relatively low levels, rather than applying high loads to provoke an ecosystem response. Together with the low background deposition in East-Poland, the levels applied resulted in addition comparable to current deposition levels in Western Europe and in the upper range of critical loads defined for rich fens. Additionally, we applied only minor levels of hydrological disturbance, resulting in minor effects on average soil moisture content, while amplifying the drying out of the soil in dry periods (Fig. 1). As such, our experiment resulted in only moderate effect sizes, but provides a realistic simulation of the subtle effects of different aspects of global change that are expected on the short term. We found that S-addition and drainage had the largest effects on fen meadow vegetation but, in concordance with the critical loads defined for fen ecosystems (Bobbink et al. 2010), the impact of $\mathrm{N}$-addition on ecosystem functioning was very limited.

\section{$\mathrm{N}$-addition}

In contrast with our hypothesis, $\mathrm{N}$-addition did not lead to a growth response of the vegetation, which would lead to the conclusion that the system is not $\mathrm{N}$-limited. This is surprising, since low foliar $\mathrm{N}: \mathrm{P}$ ratios measured in our experiment, which were all well below 14, are normally associated with N-limited plant growth (Koerselman and Meuleman 1996). Additionally, fertilization experiments in comparable fens in the near vicinity of the study site $(<1 \mathrm{~km})$ showed that these were $\mathrm{N}$-limited and showed $\mathrm{N}: \mathrm{P}$ ratios consistent with those measured in our 
Table $2 \mathrm{~N}$ and $\mathrm{P}$ stoichiometry data of plant and total vegetation biomass for the $\mathrm{N}$ and $\mathrm{S}$ treatments. Mean values are given with SEM between brackets

\begin{tabular}{|c|c|c|c|c|}
\hline & $-\mathrm{N}$ & $+\mathrm{N}$ & $-\mathrm{S}$ & $+\mathrm{S}$ \\
\hline \multicolumn{5}{|c|}{ Plant $\mathrm{N}$ concentration $(\mathrm{mg} \mathrm{N} / \mathrm{g}$ ) } \\
\hline $2007^{\mathrm{a}}$ & $10.42(0.63)$ & $10.16(0.55)$ & $10.04(0.59)$ & $10.56(0.59)$ \\
\hline 2008 & $14.57(0.43)$ & $14.21(0.61)$ & $13.65(0.43)$ & $15.1(0.52)$ \\
\hline 2009 & $17.27(0.63)$ & $17.11(0.42)$ & $17.10(0.75)$ & $17.29(0.30)$ \\
\hline \multicolumn{5}{|c|}{ Plant $\mathrm{P}$ concentration $(\mathrm{mg} \mathrm{P} / \mathrm{g}$ ) } \\
\hline $2007^{\mathrm{a}}$ & $1.67(0.10)$ & $1.73(0.10)$ & $1.69(0.10)$ & $1.72(0.11)$ \\
\hline 2008 & $1.57(0.05)$ & $1.47(0.07)$ & $1.5(0.07)$ & $1.53(0.05)$ \\
\hline 2009 & $1.95(0.08)$ & $1.86(0.09)$ & $2.04(0.07)$ & $1.76(0.09)$ \\
\hline \multicolumn{5}{|c|}{ Plant N:P ratio } \\
\hline $2007^{\mathrm{a}}$ & $6.89(0.73)$ & $6.27(0.39)$ & $6.29(0.52)$ & $6.84(0.59)$ \\
\hline 2008 & $9.49(0.30)$ & $9.49(0.41)$ & $8.98(0.28)$ & $9.97(0.37)$ \\
\hline 2009 & $9.09(0.47)$ & $9.67(0.51)$ & $8.45(0.44)$ & $10.22(0.46)$ \\
\hline \multicolumn{5}{|c|}{ Plant phosphatase activity $\left(10^{-2} \mathrm{mg} 4-\mathrm{NP} / \mathrm{g} / \mathrm{hr}\right)$} \\
\hline $2007^{\mathrm{a}}$ & $1.51(0.22)$ & $1.77(0.24)$ & $1.67(0.19)$ & $1.61(0.27)$ \\
\hline 2008 & $1.88(0.17)$ & $2.45(0.32)$ & $2.14(0.27)$ & $2.16(0.24)$ \\
\hline 2009 & $3.7(0.50)$ & $4.07(0.41)$ & $4.05(0.51)$ & $3.69(0.39)$ \\
\hline \multicolumn{5}{|c|}{ Biomass $\mathrm{N}$ concentration $(\mathrm{mg} \mathrm{N} / \mathrm{g}$ ) } \\
\hline 2007 & $13.06(0.38)$ & $12.76(0.37)$ & $12.93(0.36)$ & $12.88(0.39)$ \\
\hline 2008 & $14.93(0.35)$ & $15.81(0.48)$ & $15.3(0.36)$ & $15.47(0.49)$ \\
\hline 2009 & $18.19(0.46)$ & $18.89(0.42)$ & $18.32(0.40)$ & $18.79(0.47)$ \\
\hline \multicolumn{5}{|c|}{ Biomass $\mathrm{P}$ concentration $(\mathrm{mg} \mathrm{P} / \mathrm{g})$} \\
\hline 2007 & $2.05(0.09)$ & $2.17(0.08)$ & $2.1(0.07)$ & $2.12(0.10)$ \\
\hline 2008 & $1.84(0.07)$ & $1.77(0.07)$ & $1.81(0.07)$ & $1.8(0.06)$ \\
\hline 2009 & $2.09(0.07)$ & $2.09(0.09)$ & $2.08(0.09)$ & $2.09(0.07)$ \\
\hline \multicolumn{5}{|c|}{ Biomass $\mathrm{N}: \mathrm{P}$ ratio } \\
\hline 2007 & $6.63(0.25)$ & $5.98(0.2)$ & $6.22(0.17)$ & $6.39(0.30)$ \\
\hline 2008 & $8.24(0.23)$ & $9.08(0.28)$ & $8.67(0.30)$ & $8.65(0.24)$ \\
\hline 2009 & $8.8(0.18)$ & $9.36(0.38)$ & $9.08(0.36)$ & $9.08(0.24)$ \\
\hline \multicolumn{5}{|c|}{ Standing stock $N\left(\mathrm{~g} / \mathrm{m}^{2}\right)$} \\
\hline 2007 & $6.26(0.35)$ & $5.56(0.25)$ & $5.69(0.29)$ & $6.13(0.33)$ \\
\hline 2008 & $12.85(1.04)$ & $11.6(0.73)$ & $12.47(0.86)$ & $11.99(0.96)$ \\
\hline 2009 & $8.60(0.47)$ & $8.55(0.70)$ & $8.74(0.47)$ & $8.42(0.68)$ \\
\hline
\end{tabular}

experiment (Wassen et al. 1998). The more realistic amounts of $\mathrm{N}$ applied in our experiment, however, were about an order of magnitude lower than in regular fertilization experiments to determine nutrient limitation. In these experiments, an excess of $\mathrm{N}$ is applied to ensure that the addition indeed leads to increased $\mathrm{N}$-availability to the vegetation (Wassen et al. 1998). This raises the question whether the low levels of $\mathrm{N}$ applied in our experiment became available to the vegetation at all. Our results showed that $\mathrm{N}$-addition did not lead to a significant increase in pore water $\mathrm{N}$ concentration nor did it affect vegetation $\mathrm{N}: \mathrm{P}$ ratios, plant $\mathrm{N}$ concentration or total standing stock $\mathrm{N}$ in aboveground vegetation biomass. A power analysis (Faul et al. 2007) showed that we should be able to detect increases in standing stock $\mathrm{N}$ as low as $0.6 \mathrm{~g} \mathrm{~N} \mathrm{~m}^{-2}$, corresponding to a fifth of the amount of $\mathrm{N}$ applied and one fifteenth of the total standing stock N, making it unlikely that we did not detect any changes because of Type II errors of our statistical analysis. We can therefore only assume that the $\mathrm{N}$ we applied did not become available to the vegetation. This suggests that the $\mathrm{N}$ we applied was either lost from the system (i.e. by leaching or denitrification; Olde Venterink et al. 2002; Song et al. 2010) or immobilized in the soil before becoming available to 

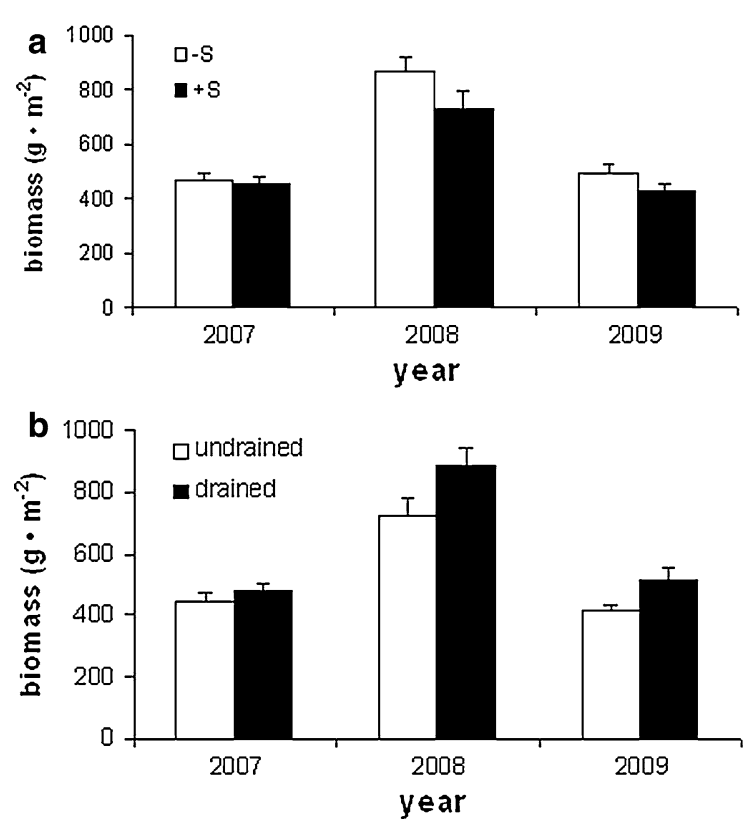

Fig. 4 a Vegetation biomass without (white bars) and with $\mathrm{SO}_{4}$ addition (black bars) over time. Differences are significant at the 0.05 level. Error bars represent standard error $(N=24)$. b Vegetation biomass in the undrained (white bars) and drained plots (black bars) over time. Differences are significant at the 0.001 level. Error bars represent standard error $(N=24)$

plants. In the 3 years that our experiment lasted, we did not find indications that $\mathrm{N}$ was accumulating in the treatments where $\mathrm{N}$ was added, although overall, pore water $\mathrm{N}$ concentrations and $\mathrm{N}$ retention in the standing biomass significantly increased over time (Table 1). Ammonium accumulation can have toxic effects on plants, especially in wet ecosystems (Stevens et al. 2011), but toxic concentrations were never reached during our experiment (Britto and Kronzucker 2002).

In conclusion, we have to reject our hypothesis that $\mathrm{N}$-addition leads to increased vegetation biomass through increased $\mathrm{N}$-availability to the vegetation.

$\mathrm{N}$-addition has been shown to increase root surface phosphatase activity as a result of increased plant P-demand, especially in ecosystems where long-term $\mathrm{N}$-deposition has led to N-saturated or P-limited conditions (Johnson et al. 1999; Robroek et al. 2009; Fujita et al. 2010). Using C. nigra as a model species, we found that $\mathrm{N}$-addition only stimulated root surface phosphatase activity under undrained conditions, as evidenced by the significant interaction between $\mathrm{N}$-addition and drainage (Table 1). However, both ambient and raised production rates measured in our experiment (both of $C$. nigra and $P$. arundinacea) were more than 3 orders of magnitude lower than were measured for comparable species under P-limited conditions (e.g. C. flacca; Phoenix et al. 2004 and $P$. arundinacea; Robroek et al. 2009). Additionally, we did not find subsequent effects of $\mathrm{N}$-addition or the combined effect of $\mathrm{N}$-addition and drainage on plant $\mathrm{N}: \mathrm{P}$ ratios or plant $\mathrm{P}$-concentrations, and we did not find a significant correlation $\left(P=0.378, r^{2}=0.130\right)$ between root surface phosphatase activity and shoot $\mathrm{P}$ concentrations in general. These results indicate that root surface phosphatase activity was extremely low under all treatments and treatment combinations and that release of inorganic phosphate from organic matter due to enzyme activity only played a minor role in phosphate uptake by the plant. As presented above, $\mathrm{N}$-addition did not result in higher $\mathrm{N}$-availability for or uptake by plants, therefore limiting the effects of $\mathrm{N}$-addition on plant P-demand. We therefore also reject our second hypothesis that $\mathrm{N}$-addition leads to increased root surface phosphatase activity and increased plant P-availability.

\section{S-addition}

Our results showed that the $\mathrm{SO}_{4}$ added in the $\mathrm{S}$-addition treatments led to significantly higher pore water $\mathrm{SO}_{4}$-concentrations in the drained treatment than in the undrained treatment, although there was considerable variation (Fig. 2). We have no reason to assume that leaching of $\mathrm{SO}_{4}$ occurred in the undrained treatment only and analysis of the biomass samples showed no significant differences in S-uptake by the vegetation between drained and undrained plots (data not shown). Other mechanisms of sulphate removal also seem unlikely: binding of sulfate to anion exchange sites are low in fen peat at circumneutral $\mathrm{pH}$ values (Scheffer and Schachtschabel 1992) and solubility constants of calcium or magnesium sulphate were not reached (Appelo and Postma 1994). We therefore suggest that, despite the only small difference in soil water content of the drained and undrained treatment, the disappearance of sulphate in the undrained treatment may have been caused by reduction to sulphide, although a more detailed analysis of the soil biogeochemistry and redox status would be needed to confirm this. De Mars and Wassen (1999), for instance, showed that even minor differences in water level in Dutch and Polish mires could lead to considerable differences in soil redox status, which 
could lead to altered $\mathrm{SO}_{4}$ concentrations, even for prolonged periods after restoration of water levels to their original position (Reiche et al. 2009).

We hypothesized that S-addition would increase P-availability, because a reduction of sulphate to sulphide in wetland soils can lead to P-release from Fe-P complexes (Lamers et al. 1998). However, contrary to our hypothesis, we did not find that $\mathrm{S}$-addition led to increased pore water $\mathrm{PO}_{4}$ concentrations, plant P-uptake or vegetation P-retention, indicating that S-induced P-release did not occur in our experiment. This may be the result of the deliberately low levels of S-addition in our experiment. The highest average pore water sulphate concentration was only $30 \mathrm{mg} / \mathrm{l}$, which is about $1 / 6$ lower than the lowest concentrations applied in the experiments of Lamers et al. (1998). However, Lamers et al. (2002a) observed (non-significant) P-release in response to increased sulphate concentrations of $48 \mathrm{mg} / \mathrm{l}$, which is only slightly higher than the concentrations measured in our experiment. Alternatively, it has been suggested that under the $\mathrm{pH}$ conditions of our soil $(\mathrm{pH}$ 6.6-7.1), $\mathrm{P}$ is complexed with $\mathrm{Ca}$ rather than with $\mathrm{Fe}$, limiting the impact of $\mathrm{S}$-addition on P-release from Fe-P complexes (Olde Venterink et al. 2002; Robroek et al. 2009).

We found that S-addition reduced plant P-uptake and vegetation biomass. S-addition significantly increased $C$. nigra $\mathrm{N}: \mathrm{P}$ ratio by reducing plant $\mathrm{P}$-content. If sulphate was indeed reduced to sulphide, these effects may result from toxic effects of sulphide on the plant roots, which can lead to reduced plant performance and vegetation productivity (Koch and Mendelssohn 1989; Smolders and Roelofs 1996). Toxic effects can occur from sulphide concentrations as low as $10 \mu \mathrm{mol} 1^{-1}$ for the most sensitive macrophyte species (Van der Welle et al. 2008), which could have easily be reached even if only part of the added sulphate in our experiment would be reduced.

\section{Drainage}

Our hypothesis that increased soil moisture dynamics due to drainage would increase vegetation biomass by increasing nutrient availability was only partly supported. Drainage did increase vegetation biomass like we hypothesized, but did not affect plant nutrient availability or uptake. Since drainage maintained high sulphate concentrations in the pore water (possibly due to prevention of sulphate reduction to sulphide), this effect may be attributed to a lack of sulphide toxicity in the drained treatment. However, this should have resulted in significant interaction effects of S-addition and the drainage treatment on vegetation biomass, which was not the case. The drainage treatment may have mitigated other detrimental effects of anaerobiosis on plant growth (including toxicity of other reduced compounds and prolonged periods of anaerobic metabolism), thereby resulting in stress relief and stimulating vegetation productivity, but we have no data to test this hypothesis.

The drainage treatment also increased soil temperatures with $0.4^{\circ} \mathrm{C}$ on average, which may have had additional positive effects on plant growth. A similar stimulatory effect of somewhat larger temperature increases was found by Updegraff et al. (2001), who showed above ground productivity increases of fen vegetation with more than $30 \%$ in response to 1.6- $-4.1^{\circ} \mathrm{C}$ temperature increases, demonstrating that limited temperature increases can have considerable effects on vegetation productivity. The susceptibility of vegetation productivity to temperature is also illustrated by the fact that the highest vegetation biomass in all treatments of our experiment was recorded in the year with the highest average temperatures in the growing period before harvesting (2008). In 2008, soil temperatures in all treatments were about $2-2.5^{\circ} \mathrm{C}$ higher and biomass levels were nearly twice as high as in the other years (Fig. 4a, b), while soil moisture contents were relatively high (Fig. 1).

The drainage treatment did not affect pore water chemistry by changing the relative input of groundwater and rainwater. Such changes can have considerable effects on plant nutrient availability and vegetation productivity (Van Dijk et al. 2004; Van Dijk et al. 2007), but the consistently high ionic ratio of the pore water showed that drainage did not affect the major ionic composition of the soil pore water by increasing rainwater input (Van Wirdum 1991).

\section{Interactive effects}

Contrary to our expectations, we found very little interactions between $\mathrm{N}$-addition, $\mathrm{S}$-addition and drainage. In addition to the interactions with drainage already discussed above, we hypothesized that $\mathrm{N}$ - and $\mathrm{S}$-addition might interact, because they can increase both plant $\mathrm{N}$ - and P-availability simultaneously, 
thereby altering $\mathrm{N}: \mathrm{P}$ stoichiometry. This may lead to higher biomass increases than can be expected for each addition separately (Güsewell 2004). We have to reject this hypothesis, however, because we did not find interactive effects of $\mathrm{N}$ - and $\mathrm{S}$-addition on any of the measured parameters. This is not very surprising in the light of our results, which indicated that the relatively low levels of $\mathrm{N}$ - and $\mathrm{S}$-addition did not affect N- or P-availability as discussed above.

Possible effects on fen plant communities

Analysis of species richness-productivity patterns in a large number of European and Eurasian wetland sites (including Biebrza valley fens) showed that increased above ground biomass production can result in species loss, especially of threatened species (Olde Venterink et al. 2003; Wassen et al. 2005). Stimulation of vegetation productivity by increased soil moisture dynamics, as we observed in our experiment, may therefore lead to species loss from these ecosystems. A reduction of vegetation productivity, on the other hand, may prevent species loss. We observed such a reduction in productivity under influence of $\mathrm{S}$-addition in our experiment. However, S-addition has been shown to have different effects on different species, favoring growth of more eutrophic fen species (Geurts et al. 2009) and may therefore result in species loss as well. C. nigra, for which we found that S-addition resulted in lower P-uptake and higher $\mathrm{N}$ :P ratios in this study, has been shown to be sensitive to sulphide (Lamers et al. 1998; Adema and Grootjans 2003), but we did not test the sensitivity of other species in the vegetation. The reduction in vegetation biomass in response to S-addition, however, suggests that other species suffered from sulphide toxicity as well. While whole community biomass and $\mathrm{N}$-uptake did not respond to $\mathrm{N}$ addition, the question remains as to whether there were compensatory responses by individual species.

\section{Conclusions}

Despite the wide co-occurrence of $\mathrm{N}$-deposition, S-deposition and global climate change and the existence of many possible mechanisms for interaction, we found little evidence for interactive effects between these three environmental problems in our experiment.

Based on the results of our experiment, We conclude that rich fen meadows, with low foliar N:P ratios that indicate $\mathrm{N}$ limitation, are quite robust to current levels of $\mathrm{N}$-deposition in Western Europe. These findings are in line with the observation that current levels of $\mathrm{N}$-deposition of European countries with high deposition levels (e.g. $30 \mathrm{~kg} \mathrm{~N} \mathrm{ha}^{-1}$ year $^{-1}$ for The Netherlands) fall within the range of critical $\mathrm{N}$ loads defined for rich fen ecosystems (15-35 kg N ha ${ }^{-1}$ year $^{-1}$; Bobbink et al. 2010).

Current levels of S-deposition (around $21 \mathrm{~kg} \mathrm{~S} \mathrm{ha}^{-1}$ year $^{-1}$ in Western European countries), however, may still have an impact on fen meadow vegetation by negatively affecting plant access to $\mathrm{P}$ and vegetation productivity. How this will affect plant community composition remains unclear.

The response of the vegetation to our drainage treatment showed that even minor alterations in soil moisture dynamics, which are expected to occur due to climate change, can considerably increase vegetation productivity, which may lead to species loss (Olde Venterink et al. 2003; Wassen et al. 2005). We found indications that the increased productivity due to altered soil moisture dynamics may be related to increased soil temperatures. This means that a stimulation of vegetation productivity by increased summer droughts may be enhanced by the temperature increases that are expected in current climate change scenarios.

Acknowledgment This research was funded by the Netherlands Organisation for Scientific Research, grant number 857.00 .010 .

Open Access This article is distributed under the terms of the Creative Commons Attribution Noncommercial License which permits any noncommercial use, distribution, and reproduction in any medium, provided the original author(s) and source are credited.

\section{References}

Adema EB, Grootjans AP (2003) Possible positive-feedback mechanisms: plants change abiotic soil parameters in wet calcareous dune slacks. Plant Ecol 167:141-149

Appelo CAJ, Postma D (1994) Geochemistry, groundwater and pollution, 2nd edn. Balkema, Rotterdam 
Bobbink R, Hicks K, Galloway J, Spranger T, Alkemade R, Ashmore M, Bustamante M, Cinderby S, Davidson E, Dentener F, Emmett B, Erisman JW, Fenn M, Gilliam F, Nordin A, Pardo L, De Vries W (2010) Global assessment of nitrogen deposition effects on terrestrial plant diversity: a synthesis. Ecol Appl 20:30-59

Britto DT, Kronzucker HJ (2002) NH4+ toxicity in higher plants: a critical review. J Plant Physiol 159:567-584

Dawson TP, Berry PM, Kampa E (2003) Climate change impacts on freshwater wetland habitats. J. Nat Conserv 11:25-30

De Mars H, Wassen MJ (1999) Redox potentials in relation to water levels in different mire types in the Netherlands and Poland. Plant Ecol 150:41-51

Faul F, Erdfelder E, Lang AG, Buchner A (2007) G*Power 3: a flexible statistical power analysis program for the social, behavioral, and biomedical sciences. Behav Res Methods 39:175-191

Fujita Y, Robroek BJM, de Ruiter PC, Heil GW, Wassen MJ (2010) Increased $N$ affects $P$ uptake of eight grassland species: the role of root surface phosphatase activity. Oikos 119:1665-1673

Geurts JJM, Sarneel JM, Willers BJC, Roelofs JGM, Verhoeven JTA, Lamers LPM (2009) Interacting effects of sulphate pollution, sulphide toxicity and eutrophication on vegetation development in fens: a mesocosm experiment. Environ Pollut 157:2072-2081

Grime JP (2001) Plant strategies vegetation processes and ecosystem properties. Wiley, Chichester

Güsewell S (2004) N:P ratios in terrestrial plants: variation and functional significance. New Phytol 164:243-266

IPCC (2007) Climate change 2007: synthesis report. Contribution of working groups I II and III to the fourth assessment report of the intergovernmental panel on climate change. IPCC, Geneva

Johnson D, Leake JR, Lee JA (1999) The effects of quantity and duration of simulated pollutant nitrogen deposition on rootsurface phosphatase activities in calcareous and acid grasslands: a bioassay approach. New Phytol 141:433-442

Koch MS, Mendelssohn IA (1989) Sulfide as a soil phytotoxindifferential responses in 2 marsh species. J Ecol 77:565-578

Koerselman W, Meuleman AFM (1996) The vegetation N:P ratio: a new tool to detect the nature of nutrient limitation. J Appl Ecol 33:1441-1450

Lamers LPM, Tomassen HBM, Roelofs JGM (1998) Sulfateinduced eutrophication and phytotoxicity in freshwater wetlands. Environ Sci Technol 32:199-205

Lamers LPM, Falla SJ, Samborska EM, van Dulken LAR, van Hengstum G, Roelofs JGM (2002a) Factors controlling the extent of eutrophication and toxicity in sulfate-polluted freshwater wetlands. Limnol Oceanogr 47:585-593

Lamers LPM, Smolders AJP, Roelofs JGM (2002b) The restoration of fens in the Netherlands. Hydrobiologia 478:107-130

Netherlands Environmental Assessment Agency (2009) National environmental outlook 2009. Netherlands Environmental Assessment Agency, The Hague

Nyíri A, Gauss M, Klein H (2010) Transboundary air pollution by main pollutants $(\mathrm{S}, \mathrm{N}, \mathrm{O} 3)$ and PM Poland. MSC-W Data Note 1/2010. Norwegian Meteorological Institute, Oslo
Olde Venterink H, Davidsson TE, Kiehl K, Leonardson L (2002) Impact of drying and re-wetting on N, P and K dynamics in a wetland soil. Plant Soil 243:119-130

Olde Venterink H, Wassen MJ, Verkroost AWM, De Ruiter PC (2003) Species-richness-productivity patterns differ between N-, P-, and K-limited wetlands. Ecology 84: 2191-2199

Phoenix GK, Booth RE, Leake JR, Read DJ, Grime JP, Lee JA (2004) Simulated pollutant nitrogen deposition increases P demand and enhances root-surface phosphatase activities of three plant functional types in a calcareous grassland. New Phytol 161:279-289

Reiche M, Hadrich A, Lischeid G, Kusel K (2009) Impact of manipulated drought and heavy rainfall events on peat mineralization processes and source-sink functions of an acidic fen. J Geophys Res 114:G02021. doi:10.1029/ 2008JG000853

Robroek BJM, Adema EB, Olde Venterink H, Leonardson L, Wassen MJ (2009) How nitrogen and sulphur addition, and a single drought event affect root surface phosphatase activity in Phalaris arundinacea. Sci Total Environ 407:2342-2348

Scheffer F, Schachtschabel P (1992) Lehrbuch der Bodenkunde, 13 th edn. Enke, Stuttgart

Smolders AJP, Roelofs JGM (1996) The roles of internal iron hydroxide precipitation, sulphide toxicity and oxidizing ability in the survival of Stratiotes aloides roots at different iron concentrations in sediment pore water. New Phytol 133:253-260

Smolders AJP, Lamers LPM, Lucassen E, Van der Velde G, Roelofs JGM (2006) Internal eutrophication: How it works and what to do about it-a review. Chem Ecol 22:93-111

Song K, Lee SH, Mitsch WJ, Kang H (2010) Different responses of denitrification rates and denitrifying bacterial communities to hydrologic pulsing in created wetlands. Soil Biol Biochem 42:1721-1727

Stevens CJ, Manning P, van den Berg LJL, de Graaf MCC, Wamelink GWW, Boxman AW, Bleeker A, Vergeer P, Arroniz-Crespo M, Limpens J, Lamers LPM, Bobbink R, Dorland E (2011) Ecosystem responses to reduced and oxidised nitrogen inputs in European terrestrial habitats. Environ Pollut 159:665-676

Updegraff K, Bridgham SD, Pastor J, Weishampel P, Harth C (2001) Response of $\mathrm{CO}_{2}$ and $\mathrm{CH}_{4}$ emissions from peatlands to warming and water table manipulation. Ecol Appl 11:311-326

Van Bodegom PM, Sorrell BK, Oosthoek A, Bakker C, Aerts R (2008) Separating the effects of partial submergence and soil oxygen demand on plant physiology. Ecology 89:193-204

van der Welle MEW, Roelofs JGM, Lamers LPM (2008) Multilevel effects of sulphur-iron interactions in freshwater wetlands in The Netherlands. Sci Total Environ 406:426-429

Van Dijk J, Stroetenga M, Bos L, van Bodegom PM, Verhoef HA, Aerts R (2004) Restoring natural seepage conditions on former agricultural grasslands does not lead to reduction of organic matter decomposition and soil nutrient dynamics. Biogeochemistry 71:317-337 
Van Dijk J, Stroetenga M, van Bodegom PM, Aerts R (2007) The contribution of rewetting to vegetation restoration of degraded peat meadows. Appl Veg Sci 10:315-324

Van Wirdum, G (1991) Vegetation and Hydrology of Floating Rich-fens. Dissertation, University of Amsterdam, The Netherlands

Visser EJW, Boegemann GM, van de STeeg M, Pierik R, Blom CWPM (2000) Flooding tolerance of Carex species in relation to field distribution and aerenchyma formation. New Phytol 148:93-103

Wang B, Qiu YL (2006) Phylogenetic distribution and evolution of mycorrhizas in land plants. Mycorrhiza 16:299-363

Wassen MJ, Olde Venterink HGM, de Swart EOAM (1995) Nutrient concentrations in mire vegetation as a measure of nutrient limitation in mire ecosystems. J Veg Sci 6:5-16
Wassen MJ, van Diggelen R, Wolejko L, Verhoeven JTA (1996) A comparison of fens in natural and artificial landscapes. Vegetatio 126:5-26

Wassen MJ, van der Vliet RE, Verhoeven JTA (1998) Nutrient limitation in the Biebrza fens and floodplain (Poland). Acta Bot Neerl 47:241-253

Wassen MJ, Olde Venterink H, Lapshina ED, Tanneberger F (2005) Endangered plants persist under phosphorus limitation. Nature 437:547-550

Working Group on Effects (2004) Review and assessment of air pollution effects and their recorded trends Working Group on Effects Convention on Long-range Transboundary Air Pollution. National Environment Research Council, London 